\title{
THE GREAT BUFFLEHEAD CRASH, 1940
}

JAMES K. FINLEY, 10232 Summerset Place, Sidney, BC V8L 4X2

On the foggy night of November $4^{\text {th }}, 1940$, citizens of Foam Lake, Saskatchewan, were disturbed by strange noises coming from outside their homes. ${ }^{8}$ Rushing outside, they were astonished to find that "a rain of ducks" was taking place. It was a ghoulish rain as some of the ducks had their wings ripped off, or their heads almost severed. Some citizens even "had the unpleasant experience of receiving a Butterball duck right on the head". The carnage lasted from 9:30 p.m. to 2:00 a.m. In the aftermath, four or five hundred ducks were picked up; all were Buffleheads, or Butterballs, as they were known colloquially. Birds were also picked up at Elfros, 18 miles northwest, and at Sheho, 18 miles southeast of Foam Lake, in a path pointing ESE (Fig. 1). Some had hit telephone wires and other obstacles, while others were uninjured. According to Dr. Chant of Foam Lake, there was a heavy fog but no snow on the ground, and there were no authentic observations of ice on the birds' plumage. The ducks were exceedingly fat, and both males and females were involved. Dr. Chant surmised that they had been weakened by a long flight and confused by the town lights. He noted that two survivors, released on water the next morning, would not fly. These facts were obtained by Mr. H.S. Swallow and published in the Canadian FieldNaturalist at the onset of the Second World War. ${ }^{8}$ The incident might have been forgotten, if an enthusiastic student of Buffleheads, Dr. Tony Erskine, had not mentioned it in his classic Buffleheads. ${ }^{5}$

Sixty years later I mentioned the story to my father, R.G. Finley, who lives on the western side of the province. I was surprised that he remembered it, though not too surprised, since he used to be a waterfowl hunter and one of the original Keemen with Ducks Unlimited. ${ }^{a} \mathrm{He}$ recalled that the accident was due to fog or sleet and the effect of streetlights that made the town appear like a lake. Still, I was puzzled by some of the facts and the explanation for the disaster, and wondered whether the event was remembered by the people around Foam Lake. Who were Swallow and Chant, I wondered.

I began dialing. The SaskTel robot responded, "What city please ?" Foam Lake. "What name please ?" Chant. Long silence, then a live operator: "I'm sorry there's no listing under that name" I asked her for any number in Foam Lake. "Maybe they might know where he is," I suggested half-truthfully. "Okay," she said gamely. "Under W, here's White, Kevin, on the farm. Stand by please for the number." This is just post-New Year's, post -Y2K.

I dialed, imagining some unsuspecting farmer on a clear cold night on the lonesome prairie, maybe watching Who Wants to be a Millionaire on television. "Hello, your name has been chosen at random, if you 


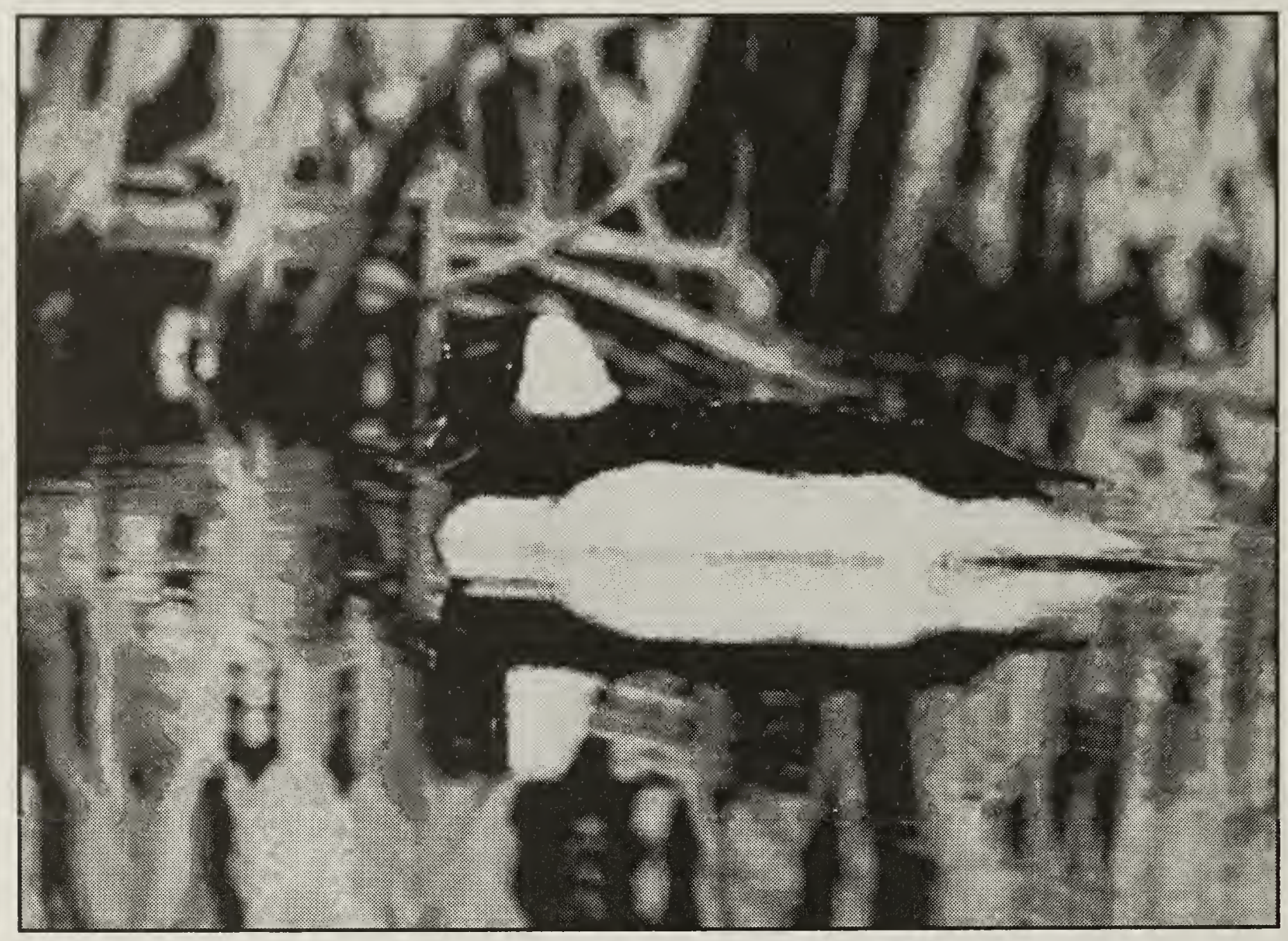

Bufflehead

P. Nicklen

remember the year of the Butterball Crash, press \# to win." A young woman answered. I stumbled. "Hello, I'm looking for a Chant, Dr. Chant, maybe he's dead now but ..., actually its about an event that happened in 1940." Mercifully she didn't hang up, but said that she'd been born nearly thirty years too late anyway. She recalled that Dr. Chant was the dentist and mayor. What event, she wondered. A rain of butterballs, I thought. "A forced landing of ducks," I replied. "Have you ever heard of Buffleheads ?" She hadn't. "Was there a Swallow living around there ?" I asked. Just barn swallows. She referred me to a local duck hunter, Ralph Hollowaty.

He hadn't heard of the event either but he knew what Buffleheads were, that they were uncommon, passing through only in migration. He referred me to local historian, Inge Helgason. She hadn't heard about the event either - her Icelandic family had arrived after the war - but she volunteered to query some elders and search the archives for back issues of the local news.

The coffee shop must have buzzed. Soon Ruth Guschulak, chairperson of the local historical society, contacted me. She said that there were very few pioneers left but she had found two fellows who still recalled the event. They were in their eighties or nineties. We talked a little about the history of the area. I learned that Sheho and Elfros were Icelandic communities. She said that the actual Foam Lake is really an alkaline slough, dry in some years, so named by settlers for its brown foam in wetter years. She said that it was now part of a heritage marsh project by Ducks Unlimited.

Mr. Willie Baptist was a drayman for the CPR railway at the time. He said that he was called to work in the morning to clean up the mess of ducks in the railway 
yards. The bodies of "mallards, greenbacks and teals" were found around the station platform; it was the only brightly-lit area in the town, he thought. He couldn't recall whether bodies were found outside the town. There were few lights back in those days, he said, and the rural area was mostly dark. The ducks had hit wires around the water tower and the arm of a baggage davit. He thought that the accident was due to a freezing rain; the ducks had ice on their bills and heads. I asked him if they ate the ducks but he couldn't recall. "Were there any Butterballs ?", I asked, thinking of the cold turkey still in our fridge, "some people know them as Buffleheads." He said that he didn't know his ducks very well, but that there were different types, "maybe greenbacks and teals."

Mr. Robert Borrowman still lives on the family farm a mile west of Foam Lake. "Chant was the dentist and the mayor," he said "but he was involved in a lot more. I think maybe the hotel in Sheho and some other businesses." Local mover and shaker, I gather. He thought that the accident was due to sleet or an ice storm. The ducks were scattered across the country from Elfros to the southeast. They were found around the CPR station in Foam Lake. "I saw them in the morning in the pasture. Maybe a couple dozen, rolling around on the ground. They had ice on their beaks and over their eyes," he said. "Different kinds, like greenbacks, mallards and teals." I asked whether he had ever heard of a Bufflehead or Butterball. He hadn't. "They were small ducks, smaller than mallards, brown and white - not your common duck, they were from the northern forests." I told him what my father had heard about the effects of fog or sleet and the town lights, making it look like a lake. He replied."There was no snow on the ground yet, it was before Remembrance Day, but I think there was a freezing shower in the evening." I asked him whether farm lights might have been a factor in the rural groundings. "Oh gawd no," he stated emphatically, "the countryside was dark in those days, there weren't any yardlights like now. They were flying high, trying to go south, when they must've iced up. You should talk to Dr. Houston, that bird fellow in Saskatoon, he'd know all about it."

I called Dr. Stuart Houston. Of course he remembered hearing about the event, though he was just a teenager living in Yorkton at the time. Swallow was the chiropractor with his office next to Houston and Houston on Broadway in Yorkton. "The business signs read in order: Houston and Houston, Swallow, Small, Guy." "Truly," he said, anticipating my skepticism "It was recorded in Ripley's Believe it or Not." Anyway, Chant, the dentist, told Swallow the chiropractor, about the event, and Mrs. Priestly, (founder of the Yorkton Natural History Society, forerunner of Nature Saskatchewan), encouraged him to submit it to the Canadian FieldNaturalist. A web of movers and shakers, I gather. Dr. Houston recalled that several hundred birds were picked up across the countryside, and he thought that the toll was probably much higher. I said that I couldn't understand how it was that the ducks ended up strewn over a rural area if lights were the main factor in their demise. Just then the phone went dead and I lost contact. And so I closed another circuit for it was Dr. Houston who encouraged me to write my first natural history note for the Blue Jay?

I also consulted Tom Sterling. He was a waterfowl biologist with Ducks Unlimited who tromped around the Quill Lakes during the 1950s. Like me, he was a prairie farm boy and a waterfowl hunter, so we had much to talk about. 
He hadn't heard of the incident; it occurred before his time. Besides, he said, he wasn't that familiar with Buffleheads, or other divers for that matter. He thought that he had heard about a nocturnal crash involving scaups. Divers were more likely than puddlers to be night migrants. He recalled great hunts for Canvasbacks as they left the Quill Lake marshes at dusk, headed out in advance of a big freeze. This was back in the fifties when the Quills were famed for waterfowl, attracting many American hunters. I asked him whether local people would know a Bufflehead by name. A few observant ones, he thought, but beyond that, ducks, particularly diving ducks, were often nameless. Divers, like scaups, were sometimes called butterballs. I mentioned that Buffleheads were also known as the Spirit Duck. He hadn't heard of any other incident of forced landing due to icing, but whatever the cause, he said, it must have been a remarkable event - just think of the interplay of factors. Indeed, the timing of their departure, the development of a frontal system, their cruising altitude, that fatal juncture of dew point, and the bright lights of Foam Lake.

We talked about the early success of Ducks Unlimited in connecting with rural people through its Keemen Program. In particular, he mentioned the role of Bert Cartwright, " a biologist-naturalist, not one of your typical bean counters" who was head of DU's Ecological Department in 1938. He lamented the gulf that seems to exist between institutional biologists and rural people.

Amazingly, Inge Helgason located the anecdote in the archives. It made the front page of the Western Review, Thursday, November $7^{\text {th }} 1940$, though you'd be hard pressed to find it, preoccupied as it was with war, Remembrance Day, municipal elections, and a shower, for the daughter of Mr. and Mrs. Sigurdur Sigbjornson. ${ }^{2}$ It appeared as the last item under the Foam Lake Locals :

\section{"The bill of fare for Foam Lake} residents has consisted largely of wild duck this week for on Tuesday morning literally hundreds of them were to be found in the streets, alleys, backyards and all over town. It seems that the ducks had made a "forced landing" during the night, owing perhaps to sleet and exhaustion and were unable to continue their flight." 2

There was no mention of anyone receiving a butterball on the head.

I was surprised to learn that the paper, now called the Foam Lake Review, was still being published. So I fed the story back as letter to the editor, hoping to snag some additional memories.

Kris Bildfell responded. Though he no longer lives in Saskatchewan, he still subscribes to the hometown news. His uncle, Mr. Lucht, used to be the publisher of the paper. He vividly remembered the event. At the time he was a teenager, living on a farm two and a half miles northwest of the town. It was an awful sight, he recalled, many of the birds had their wings or heads ripped off, after hitting wires and other objects. When he arrived at school, he and other boys were sent out to dispatch the wounded. Many were hiding in the tall grass around the schoolyard. He didn't know their name, just that they were unusual and small like teals. I asked him whether the bill of fare for the townsfolk was roast duck. He didn't think so; they were told not to eat them because it was uncertain what was wrong with them, war and Halloween and all. I asked him about the icing hypothesis and whether the birds were strewn across the country. He didn't recall that there was any ice 
on the ducks but he was confident that the birds were found only in the town, particularly around the brightly-lit area of the "creamery yard". I asked him whether anyone had received a butterball on the head. He hadn't heard of it, nor had anyone else I talked to.

The Great Bufflehead Crash of 1940 was a remarkable event. Swallow's account is still echoed in the verbal knowledge of the few elders in Saskatchewan. Local knowledge, an anecdote in the Blue Jay or the Canadian Field-Naturalist, when woven together with scientific facts, provides the warp and weft of natural history. Swallow's account was incorporated into Buffleheads, the monograph by Dr.
Erskine, and became part of the lore of this interesting species.

The drama and mechanics of waterfowl migration greatly impressed Erskine. "Anyone, whether hunter or not, who watches the duck flocks pouring out of the north during a mass migration in the fall can hardly fail to be thrilled with the sight."6 Yet he could only imagine Bufflehead migration since it occurred at night; the crash at Foam Lake gave him an inkling of the nocturnal peregrinations of his subject, which he worked into his thesis concerning weather patterns. The timing of the crash was consistent with peak movements in early November through U.S. National Wildlife Refuges,

Figure 1. Conjectured migration route of Buffleheads across the aspen parkland belt of Saskatchewan on the evening of November $4^{\text {th }}, 1940$.

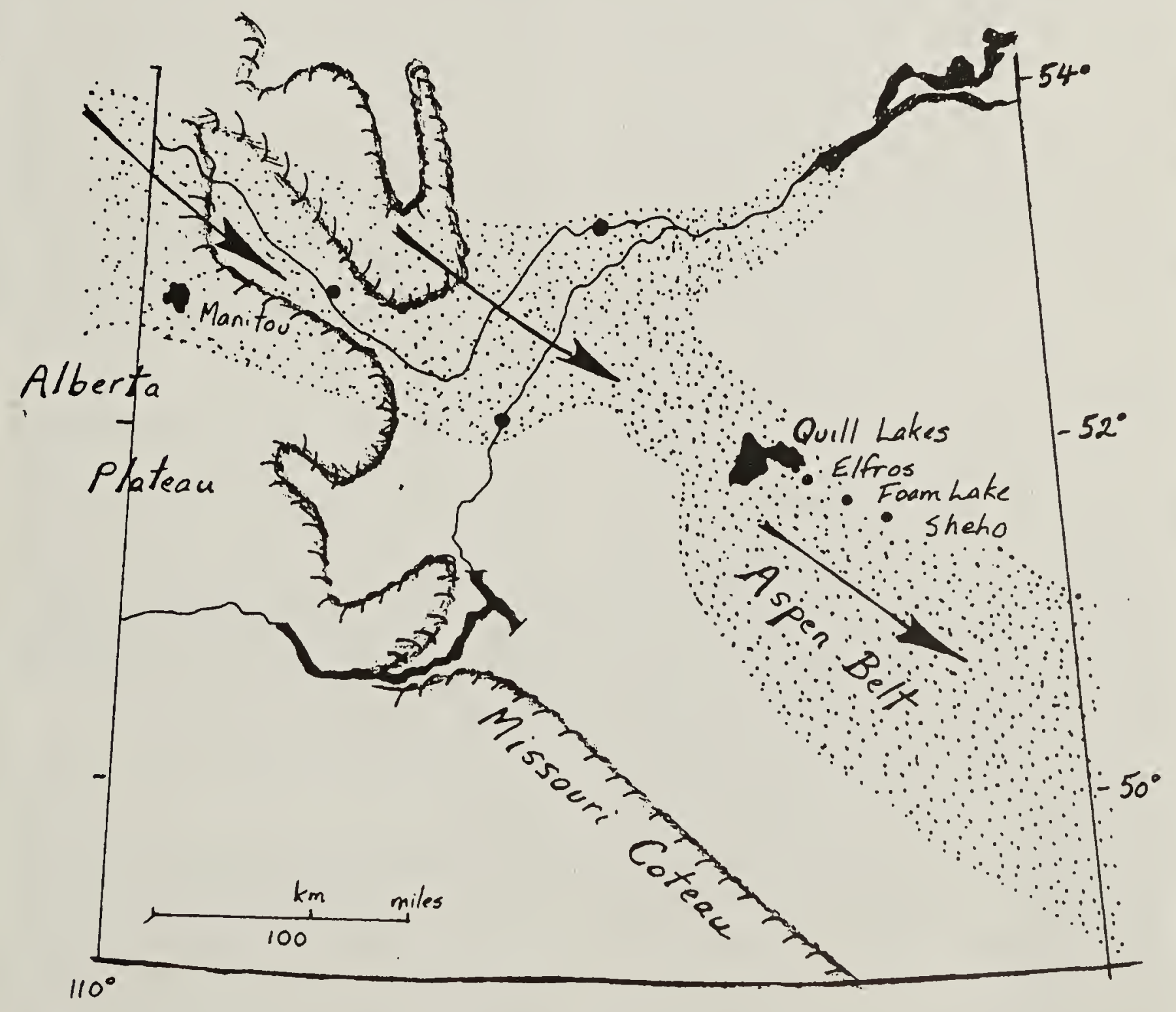


following major polar fronts sweeping over the Canadian prairies. Storm riders, their mass exodus signifies the real end of autumn, when the accumulated energy of large sloughs slips below zero on the surface.

Let's take a few more facts, some personal experience, and spin the scenario again.

Last of the waterfowl to remain on the breeding grounds, Buffleheads fatten up through October, packing on as much as 115 grams of stored fat for their flight. ${ }^{5,6}$ No wonder they're called butterballs, that's nearly a third of their weight! Just before freeze-up they aggregate on the larger sloughs, feeding voraciously, waiting for a boost from the first major arctic gale. Rafting together in late afternoon, they find shelter on the lee shore, then at dusk they taxi to the centre of the slough, face about, and take off in squadrons, banking sharply off the northwest winds, quickly achieving cruising speed. They head southeast, following the aspen parkland belt toward their wintering grounds on the Atlantic coast. The squadrons form a phalanx of storm riders that pours off the Alberta plateau and flows down the North Saskatchewan River valley. Let's say their departure time on November $4^{\text {th }}$ is $1715 \mathrm{~h}$, somewhere between latitude 53 and 54, and centered around longitude 110 . They take a SE bearing of $110^{\circ}$, and rise to an altitude of 1.5 $\mathrm{km}$ to take maximum advantage of the wind. ${ }^{1}$ Their cruising speed is $65 \mathrm{~km} /$ hour, boosted to around 100. Fact: although Buffleheads banded on their breeding grounds in east-central Alberta have been shot in 36 states and five provinces, none has yet been recovered in Saskatchewan and only one in Montana, which suggests that these areas are crossed in a single flight. ${ }^{6}$ Erskine thought that Buffleheads flew through the night, "although bright moonlight might permit them to land earlier". ${ }^{5}$ By dawn they could be on Lake Erie, but on this particular night some strange brew of weather catches them over Saskatchewan. Around 2100h, the vanguard pass over the steaming Quill Lakes and enter into a dense fog. First Elfros, then the bright lights of Foam Lake, then Sheho, they become disoriented, crashing in a band pointing ESE. The citizens, tuned into the war news, are unaware that the Spirit Ducks are about to descend. A rain of butterballs takes them by surprise.

Next morning, those rescued refuse to fly. Why ? Because they were programmed to fly at night, guided by the constellations. Many bird species migrate under the cover of night with the aid of favourable winds, and many millions are fatally attracted like moths to artificial lights. Combine bad weather and the results can be disastrous, particularly around tall structures. For example, on a foggy September weekend in 1981, more than 10,000 passerines collided with floodlit smokestacks at Ontario Hydro's generating station on Lake Erie. ${ }^{3}$ Most of the major disasters involve passerines.

Buffleheads continue to take the long route (round trip of about 6000 kilometres) to their Atlantic wintering grounds, across an increasingly illuminated landscape, yet neither their timing nor the particular circumstances of weather have been as congruent as that fateful night in 1940 .

From Elfros to Sheho the Butterballs traveled.

Like Ariadne's thread the web unraveled.

${ }^{a}$ R.G. Finley of Luseland, Sask. received an award for sixty years of service. "Keemen" were farmers and 
ranchers with an interest in waterfowl conservation who reported on environmental conditions and waterfowl populations.

\section{Acknowledgements}

To Houston and Houston, Swallow, Small, Guy, add Chant, Priestley, Erskine, White, Hollowaty, Helgason, Guschulak, Baptist, Borrowman, Sterling, Bildfell and my own, R.G. Finley. Thanks to Dr. C.S. Houston and the Leightons for editorial input. In memory of J.B. Gollop

1. Alerstam, T. and G.A. Gudmundsson. 1999. Migration patterns of tundra birds: tracking radar observations along the Northeast Passage. Arctic 52 : 346 371.

2. Anonymous. 1940. Foam Lake Locals. The Western Review 24 : 45
4. Erskine, A.J. 1960. A discussion of the distributional ecology of the Bufflehead (Bucephala albeola: Anatidae; Aves) based upon breeding biology studies in British Columbia. M.A. Thesis. University of BC, Vancouver, BC

5. Erskine, A.J. 1971. Buffleheads. Canadian Wildlife Service Monograph Series \#4. Information Canada, Ottawa. $240 \mathrm{p}$.

6. Erskine, A.J. 1999. Bufflehead. Canadian Wildlife Service. Hinterland Who's Who Series. 4 p.

7. Finley, J. K. 1972. A 1921 photograph of whooping crane. Blue Jay 30:151.

8. Swallow, H.S. 1941. Rain of ducks at Foam Lake, Saskatchewan. Canadian Field-Naturalist. 55: 130.

3. Bower, J. 2000. The dark side of light. Audubon Magazine March/April Vol. 102 (2): 92-97

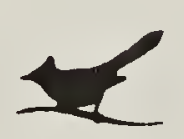

"I have procured some of the mice mentioned in my former letters, a young one and a female with young, both of which I have preserved in brandy. From the colour, shape, size and manner of nesting, I make no doubt but that the species is nondescript. They never enter into houses. They breed as many as eight at a litter, in a little round nest composed of the blades of grass or wheat."

Gilbert White, The Natural History of Selbornel, 1789. (First description of the Harvest Mouse, Micromys minutus) 